\title{
Southern Minnesota: An Evolving Alternate Energy Frontier
}

\author{
Martin Mitchell ${ }^{1}$ \\ ${ }^{1}$ Dept. of Geography, Minnesota State University, Mankato MN, USA \\ Correspondence: Martin Mitchell, Dept. of Geography, Minnesota State University, Mankato MN 56001, USA. \\ E-mail: martin.mitchell@mnsu.edu
}

$\begin{array}{lc}\text { Received: May 6, } 2013 & \text { Accepted: June 20, } 2013 \quad \text { Online Published: June 24, } 2013 \\ \text { doi:10.5539/jgg.v5n3p43 } & \text { URL: http://dx.doi.org/10.5539/jgg.v5n3p43 }\end{array}$

\begin{abstract}
A combination of physical environmental variables and government policies centered on mandates and production subsidies have led to a robust growth in alternative energies in southern Minnesota. Centered on wind turbine generated electricity and bio-fuels associated mostly with corn based ethanol and soybean-based diesel, these developments provide an example of how state and federal policies can work successfully in tandem with private enterprise to create a new energy frontier in a region lacking in traditional fossil fuel energy resources and feedstocks. The Minnesota example also illustrates how substitution strategies differ from conservation initiatives and distinguishes the differences associated with electrical generation versus the dependency of fossil-based liquid fuels for the transportation sector of the U.S. economy, a situation replicated in Canada.
\end{abstract}

Keywords: base and variable load power, wind turbines, ethanol, bio-diesel, renewable energy standard (RES)

\section{Background}

Known for its vast till plains with their production of corn and soybeans, southern Minnesota would seem an unlikely region for harboring a growing energy sector. Devoid of traditional fossil fuels (coal, oil and natural gas) and possessing very limited potential for hydroelectric power, Minnesota has depended traditionally on imports of energy feedstocks from other states and countries. The recent rise of a robust biofuels sector and wind energy industry has countered this tradition though not alleviated it.

Stated as a national goal since the first Organization of Petroleum Exporting Countries (OPEC) embargo in late 1973, energy independence for the United States must be understood in the context of energy usage. First, various energy feedstocks are used to essentially boil water, create steam, drive turbines and operate generators producing electricity. Electrical power generation occurs in two contexts: (a) base load power available 24/7 and (b) variable load power produced as demand peaks and then throttled down or shut-off as demand declines. Second, liquid fuels derived from petroleum are used to power the transportation system and supply a steady stream of agro-chemicals and synthetic products such as polymers. Pursuant to energy independence, the latter has proved vastly more challenging as energy dependence on a single fungible feedstock, crude oil, remains the rule albeit some exceptions have begun to appear.

Two of these exceptions, corn based ethanol and biodiesel, have found a sound starting place in Minnesota which has been on the frontier or leading edge of American states in fostering a renewable energy industry at a commercial scale. Along with California and a host other states such as Texas and Iowa, Minnesota has proved to be a fertile frontier for producing electricity by means of wind turbines

\section{Electrical Generation}

In 1977, President Carter made a concerted policy effort to wean U.S. electrical generation from petroleum (oil). Accomplished through shifts to coal, nuclear, natural gas and of late, wind energy, policies such as the Surface Mining and Reclamation Act of 1977 encouraged the expansion of regulated open pit coal mining (Statutes at Large 1977). Typified by back-up generators and small units located in isolated locales such as western Alaska, petroleum accounted for less than 1\% of electrical generation in 2012 (U.S. EIA, 2013a). Responding to domestic and Canadian concerns pertaining to acid rain, Congress passed the Clean Air Act of 1990, which targeted sulfur dioxide emissions with a cap and trade system of regulation that fostered a substitution of low sulfur $(<1 \%)$ sub-bituminous coals from Wyoming's Powder River basin for the high sulfur coals of southern Illinois/Indiana and the Appalachians. This substitution combined with the installation of electro-static precipitators (scrubbers) allowed for increased coal production and consumption by electrical utilities. 
Commensurate with a shift towards coal, nuclear power plant construction surged in the late 1970 s, as did uranium mining, which peaked in 1983 (Uranium Producers of America, 2013). However, the Three Mile Island incident in 1979 resulted in a cessation of new nuclear power permits with the last U.S. civilian reactor coming on-line in 1985. More recently, the Energy Independence Act of 2005, by exempting hydraulic fracturing (fracking) from federal regulation under the Safe Water Drinking Act, has resulted in a substantial increase in domestic natural gas production with prices plummeting nearly $70 \%$ since 2008 . Natural gas has found environmental favor from a climate change standpoint because it produces about $42 \%$ less $\mathrm{CO}_{2}$ per billion BTUs of heat produced (EIA, 2013b). Indeed, U.S. $\mathrm{CO}_{2}$ emissions from electrical power generation actually declined from 2.41 billions short tons in 2001 to 2.28 billion short tons in 2011 (U.S. EIA, 2013a). Similarly, $\mathrm{SO}_{2}$ emissions dropped from a 1980 base of 18.5 million short tons/year to 4.8 million short tons in 2011 (Clean Air Act 1990, Title IV and U.S. EIA, 2013a).

Consequently, the United States to a certain extent possesses energy independence relative to electrical generation. The only exceptions are: (1) natural gas imports from Canada, which in 2011 are on the decline in the face of increased domestic production borne of fracking tight shale formations, (2) imports of electricity generated in Canada and Mexico that in 2011 accounted for $<1 \%$ of U.S. demand, and (3) uranium imports from Canada and Russia, which supplied 90\% of the U.S. civilian nuclear power needs (U.S. EIA, 2013a, 2012). This latter figure dramatically reflects the decline of domestic uranium mining starting in 1985 and the long-standing U.S. policy of prohibiting the civilian industry from reprocessing spent fuel so as to limit the supply of nuclear weapons grade plutonium.

\subsection{Wind Turbines}

Part of the electrical success involves the rise of a new electrical enterprise, namely wind turbines. Although supplying only $3 \%$ of the U.S. total and generating variable load rather than base load power, wind energy can be very significant at a local or regional level. Minnesota provides an ideal example where in 2010 its leading utility, Xcel Energy, produced $19 \%$ of its electricity from renewable sources with wind power being the overwhelming supplier (Minnesota, 2011). Overall, Minnesota ranks in the second tier of wind producers with installed capacities of 2,900 to 3,500 MW through 2012. Texas, California and Iowa comprise the first tier with installed capacities of over 5,000 MW and in the case of Texas, 12,200 MW through 2012. However, Minnesota was one of the first states to have more than $200 \mathrm{MW}$ of capacity at the close of the $20^{\text {th }}$ century (Windpowering America, 2012).

The rise of wind energy in Minnesota derives from a combination of physical geographical variables and the interactions of federal and state policies. The U.S. Government's inability to construct and operate a nuclear repository for spent nuclear fuel from civilian reactors forced nuclear power generators such as Minnesota's Xcel Energy to pursue other interim storage options such as dry cask storage as their short-term spent fuel water tanks reached capacity. Dry cask storage involves impounding spent fuel inside a cask constructed of multiple layers of steel and concrete. In 1994, the Minnesota Legislature mandated that Xcel Energy produce or purchase at least $425 \mathrm{MW}$ of its electricity from renewable sources as a condition for permitting dry cask storage at the Prairie Island nuclear facility (National Renewable Energy Lab, 1999). This renewable energy standard (RES) has been revised twice with the most recent iteration in 2007 calling for Xcel to produce or purchase an $18 \%$ of its power from renewable sources. As of 2010, Xcel reached a $19 \%$ threshold. Statewide the RES stands at $12 \%$ with a $14 \%$ generation as of 2010 (Table 1). By 2020, the RES for Xcel Energy will increase to $31 \%$ and $20 \%$ for other utilities (North American Water Office, 2008; Minnesota, 2011). The latest evolution of the RES occurred in 2013 with the state modifying the 2020 goals to include a $1.5 \%$ solar generation by Xcel and other publically owned utilities (US DOE, 2013). 
Table 1. Minnesota electrical consumption by energy source, 2010

\begin{tabular}{lr}
\hline Energy Source & Percentage of state total \\
\hline Coal & $51 \%$ \\
Nuclear & $25 \%$ \\
Natural Gas & $6 \%$ \\
Wind & $8 \%$ \\
Biomass & $4 \%$ \\
Hydro-electric & $2 \%$ \\
Imports* & $4 \%$ \\
\hline
\end{tabular}

* Surrounding States and Manitoba.

Source: US Energy Information Agency, 2013.

Located in southwestern Minnesota, Buffalo Ridge escaped the leveling effects of the last glacial onslaught and consequently rises about 800 feet $(240 \mathrm{~m})$ above the regional terrain (Figure 1). The passage of warm and cold fronts in the context air mass convergences favors windy conditions in the fall, winter and spring while during the summer, the polar front jet, anchored along the north shore of Lake Superior, provides for sustained southerly flow of unstable maritime tropical air from the U.S. Gulf Coast punctuated by westerly or northwesterly flow as weak cold fronts advect across the region. Taken together, these climatic and physiographic variables result in average wind velocities of $20 \mathrm{mph}(9 \mathrm{~m} / \mathrm{sec})$ at an elevation of 250 feet $(80 \mathrm{~m})$ above the ridgeline. In contrast, wind velocities 250 feet $(80 \mathrm{~m})$ above the regional datum off the ridge average only $15 \mathrm{mph}$ (7 m/sec) (Minnesota, 2008).

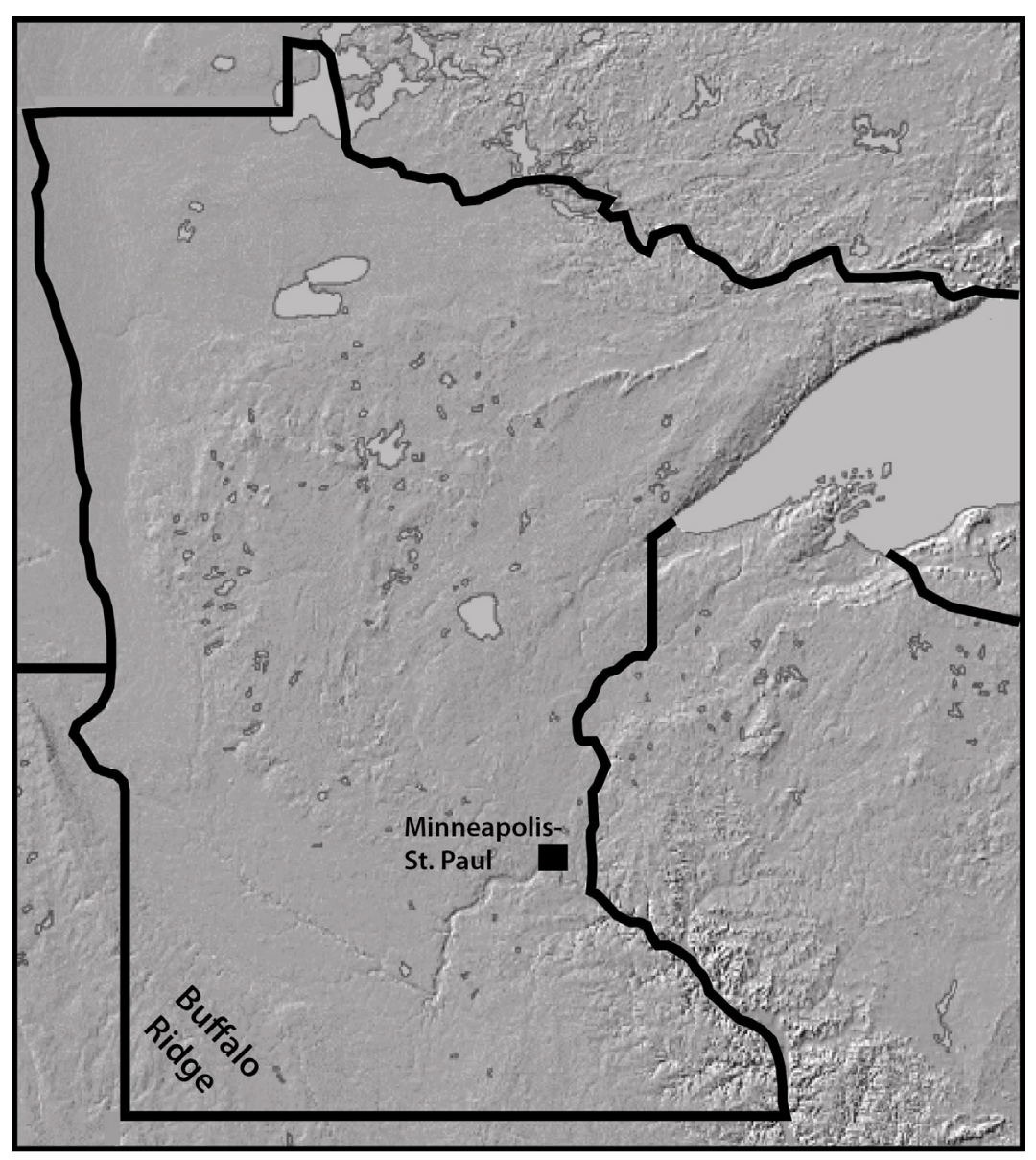

Figure 1. Buffalo Ridge in Southwestern Minnesota 
Due to the permit conditions associated with the 1994 dry cask storage agreement between Xcel Energy and the state of Minnesota, wind turbines soon appeared on Buffalo Ridge. Patterned after units installed in the middle to late 1980's in California, the early units stood about 125 feet high $(40 \mathrm{~m})$ and featured high velocity turbines with limited blade length and a $330 \mathrm{KW}$ capacity per unit, an improvement over the $100 \mathrm{KW}$ capacity of the California turbines (Nelson, 2009). By 1999, installed capacity in Minnesota stood at 273 MW (Windpowering America, 2012).

Facilitated by a federal energy production tax credit and additional revisions in Minnesota's RES, a dramatic expansion occurred over the next 12 years, with capacity reaching 2,900 MW in 2012 (Windpowering America, 2012) (Figure 2). The capacity increase paralleled technological developments in the wind turbine industry as second and third generation turbines became commonplace. Based on Danish designs, these newer turbines featured higher towers 225 feet $(70 \mathrm{~m})$ and longer blade lengths of 70-80 feet $(25 \mathrm{~m})$ and capacities of $650-750$ KW (Figure 2) (Righter, 2011). Deceiving when viewed first hand because these turbines spin slowly (14 revolutions per minute), yet because of their size, the blades tips actually rotate at $105 \mathrm{mph}$ (170 kmh). More recent installations of fourth generation turbines mounted on 250 -foot $(80 \mathrm{~m})$ platforms with blade lengths of 120 feet $(40 \mathrm{~m})$ possess still larger capacities of 1.5 to 3.0 MW per unit (Figure 3).

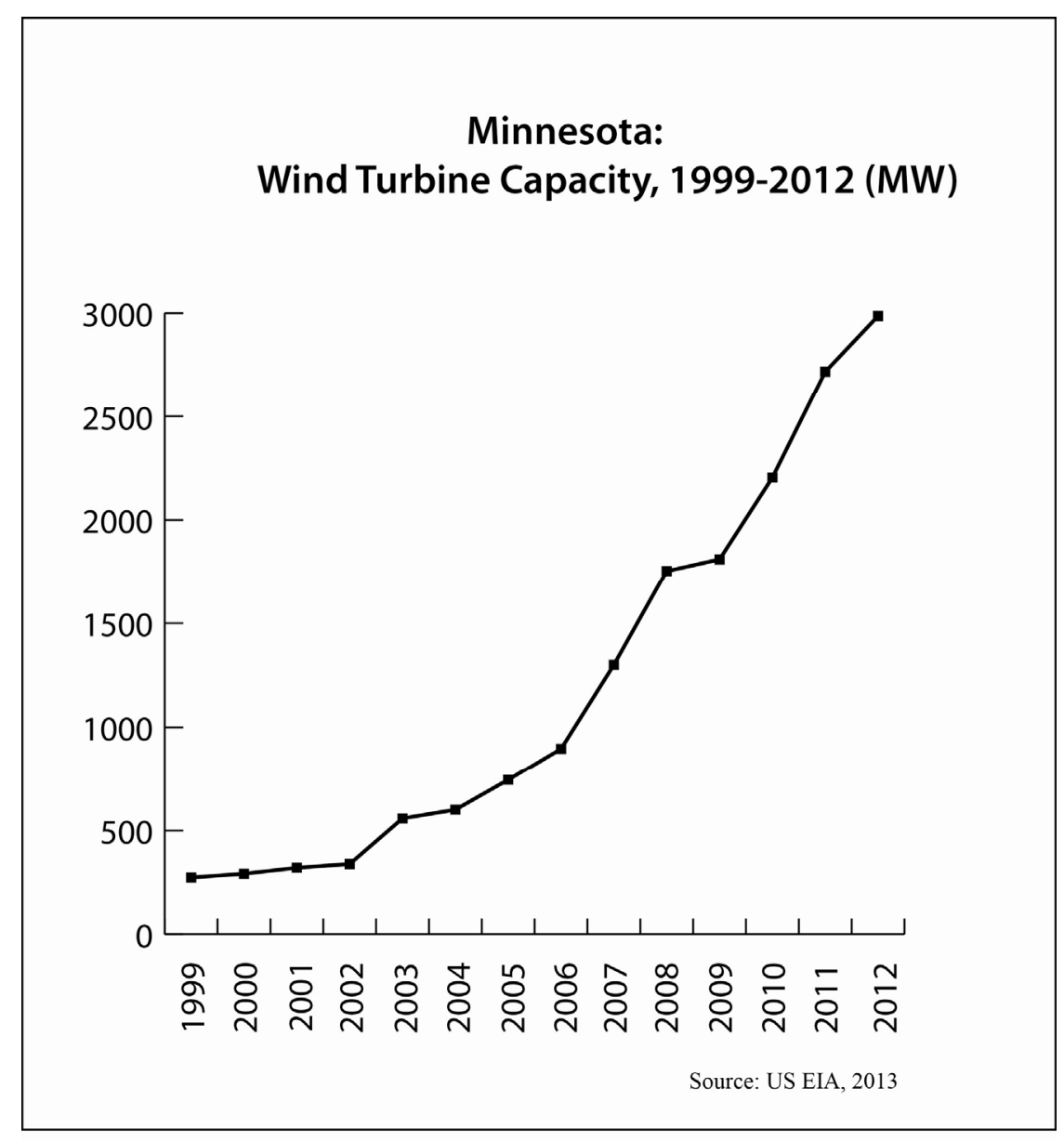

Figure 2. Installed wind Turbine capacity in Megawatts, 1999-2012 


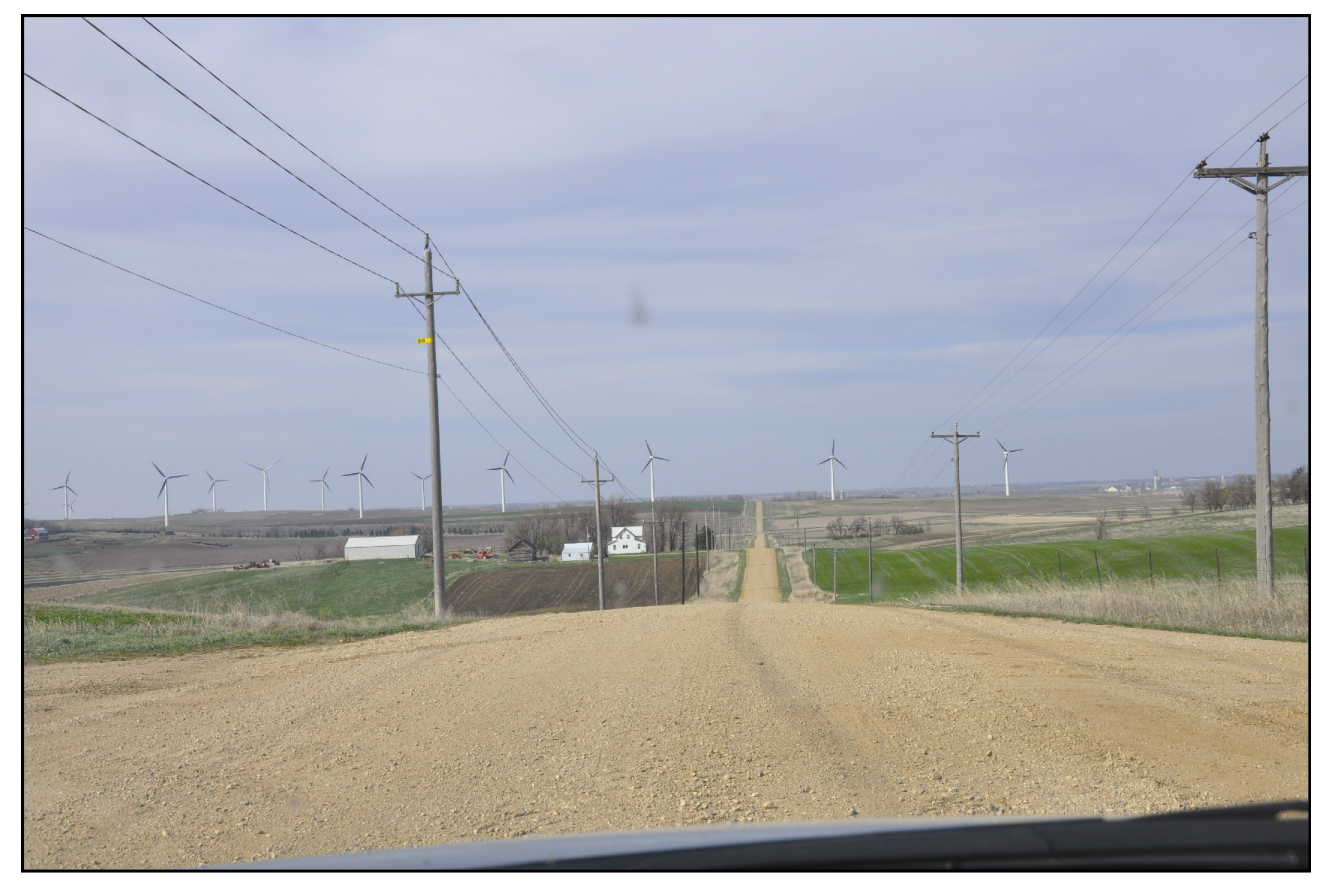

Figure 3. Wind Turbines on Buffalo Ridge, MN. Black blades are 650-750 KW and the unit with white blades has a $1.5 \mathrm{MW}$ rating

Capacity, however, does not explain actual electrical production or yield. Operating at $25-30 \%$ capacity, Minnesota's wind turbines yield about 675-825 MW of power, a substantial amount when considering the state's three nuclear reactors average $625 \mathrm{MW}$ each (Righter, 2011). In addition to the turbine units, the electrical transmission lines from Buffalo Ridge to the Minneapolis-St. Paul metropolitan area have been built anew or upgraded. Finally, the wind turbine industry has produced a capital flow from the Twin Cities into a sparsely populated rural section of Minnesota lacking the economic base opportunities present in the state's metropolitan areas. This capital flow stems from lease fees paid to rural landowners to host the turbines and the employment of a skilled labor force to install new units and maintain the existing turbines (Hoff \& Peterson, 2003).

Although renewable and considered green, the wind turbines of southwest Minnesota are not without environmental concerns. Aesthetics, noise and avian impacts are the chief complaints leveled against the wind turbines. Aesthetic impacts are arguably very subjective. What one might consider an eyesore on the open prairie landscape, another may view as environmental progress or simply a graceful expression of alternative energy. Noise impacts are another subjective variable. Standing along side a gravel road in the midst of dozens of turbines, one can easily discern a steady low-pitched hum resembling the idle of a distant prop driven airplane. Given the sparsely populated environs of Buffalo Ridge, these impacts are negligible (Minnesota, 2009). Assumedly, in a suburban or densely populated rural setting both the noise and aesthetic impacts may take on greater importance. Avian impacts comprise yet another concern. A British study of wind turbines in an intensively farmed area of the U.K. found negligible impacts pursuant to birds (Science Daily, 2008). A Canadian study found that halting the turbines at night when demand is typically low resulted in substantive reduction of bat deaths (Science Daily, 2009). In Minnesota, no significant problem associated with birds or bats has been documented. What can be said about wind turbines is that the local setting and regional scale relative to avian wildlife and human population patterns are critical when assessing potential aesthetical, noise and avian impacts.

\section{Liquid Fuels: Ethanol}

In 1979, the United States consumed about 18.6 million barrels per day (bbls/day) of crude oil and in 2012 some 30 plus years later, oil consumption remained at roughly 18.5 million bbls/day (US EIA, 2013c). In 1979, oil consumption was spread between transportation, industrial operations and electrical generation, albeit transportation comprised the largest sectoral use. In 2011, the transportation sector consumed $70 \%$ of the national crude oil total. Specifically, the transportation sector used 8.7 million bbls/day for gasoline, 2.6 million bbls/day for diesel and another 1.4 million bbls/day for jet fuel. When including farm and construction equipment, diesel consumption approaches 3.0 million bbls/day (US EIA, 2013c). 
Unlike electricity, energy independence pursuant to transportation has been a near total failure. I argue this failure can largely be explained by a combination of: (1) relaxing the Corporate Auto Fleet Efficiency (CAFÉ) standards during the 1990s, (2) a deliberate ramping-up of Saudi production in the 1980's to flood the market with oil, thereby, driving down prices and furthering the economic pressures on the Soviet Union as its foreign exchange earnings plummeted while trying to maintain a costly arms race with the U.S.A., (3) a complete lack of meaningful research and development by the American auto and trucking industries in technologies that would sever the connection to petroleum based fuels or substantially reduce it, and (4) a failure to reassess the Cold War stratagem regarding oil in a post Cold War setting especially given the industrialization of China and India and the accentuated instability associated with Islamist movements in the Middle East. The only bright spot is that the U.S. economy is not as oil intensive relative the 1970's. Although true, this statement is predicated on the off-shoring of much industry to China and other developing countries, and consequently hides or masks, oil dependency relative to the plethora of manufactured goods purchased regularly by American consumers.

\subsection{Ethanol}

The rise of a commercially viable bio-fuels industry over the past 12 years, mostly in the context of corn based ethanol, has taken on regional significance in the U.S. Midwest with Minnesota being no exception. Ethanol distillation comprises a small but important step towards liquid fuel independence because unlike conservation strategies that simply use petroleum more efficiently, bio-fuels stand as substitutes or replacements for petroleum derived gasoline. Lacking the BTUs per unit relative to gasoline (77,000 vs. 116,000), but possessing a higher octane, one unit of ethanol substitutes for about .85 units of gasoline (Alternative Fuels Data Center, 2013).

Ethanol production in Minnesota increased from 204 million gallons (772 million liters) per year in 2000 to 1.1 billion gallons ( 3.9 billion liters) in 2012 with slightly over $70 \%$ of the state's production being shipped to other states (Minnesota 2012) (Table 2). This production increase parallels the national trend of ethanol increasing from 1.62 billion gallons ( 6.13 billion liters) in 2000 to nearly 13 billion gallons (50 billion liters) in 2012 (Nebraska 2013). The state's 21 ethanol distillation plants, 10 of which are owned by farmer co-operatives, are located throughout the rural portions of southern Minnesota along rail lines because ethanol cannot be transported by conventional petroleum pipelines due to its more corrosive nature (Figures 3 and 4) (Minnesota, 2012). Powered by American coal or American/Canadian natural gas, the 21 distillation units in Minnesota calculate to a reduction of 935 million gallons ( 3.5 billion liters) of gasoline per year (Figure 5). Nationally, the ethanol induced gasoline reduction equates to 11.9 billion gallons ( 45 billion liters) or $650,000 \mathrm{bbls} /$ day of crude oil.

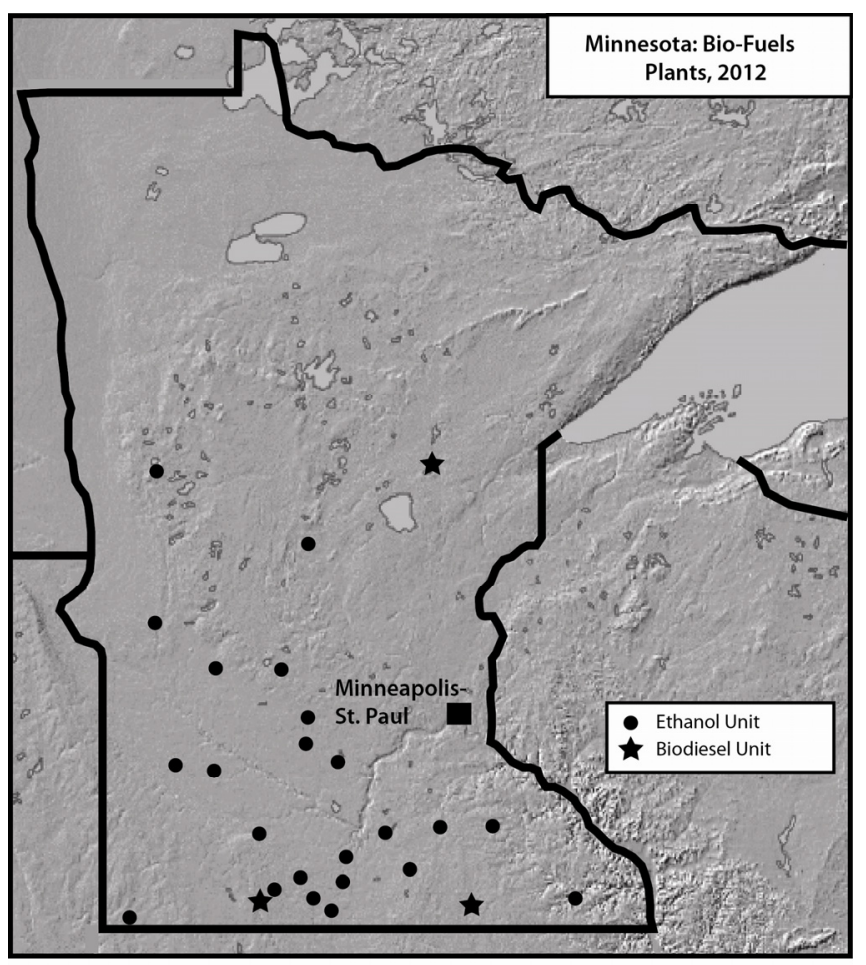

Figure 4. Biofuel production units in Minnesota, 2012 


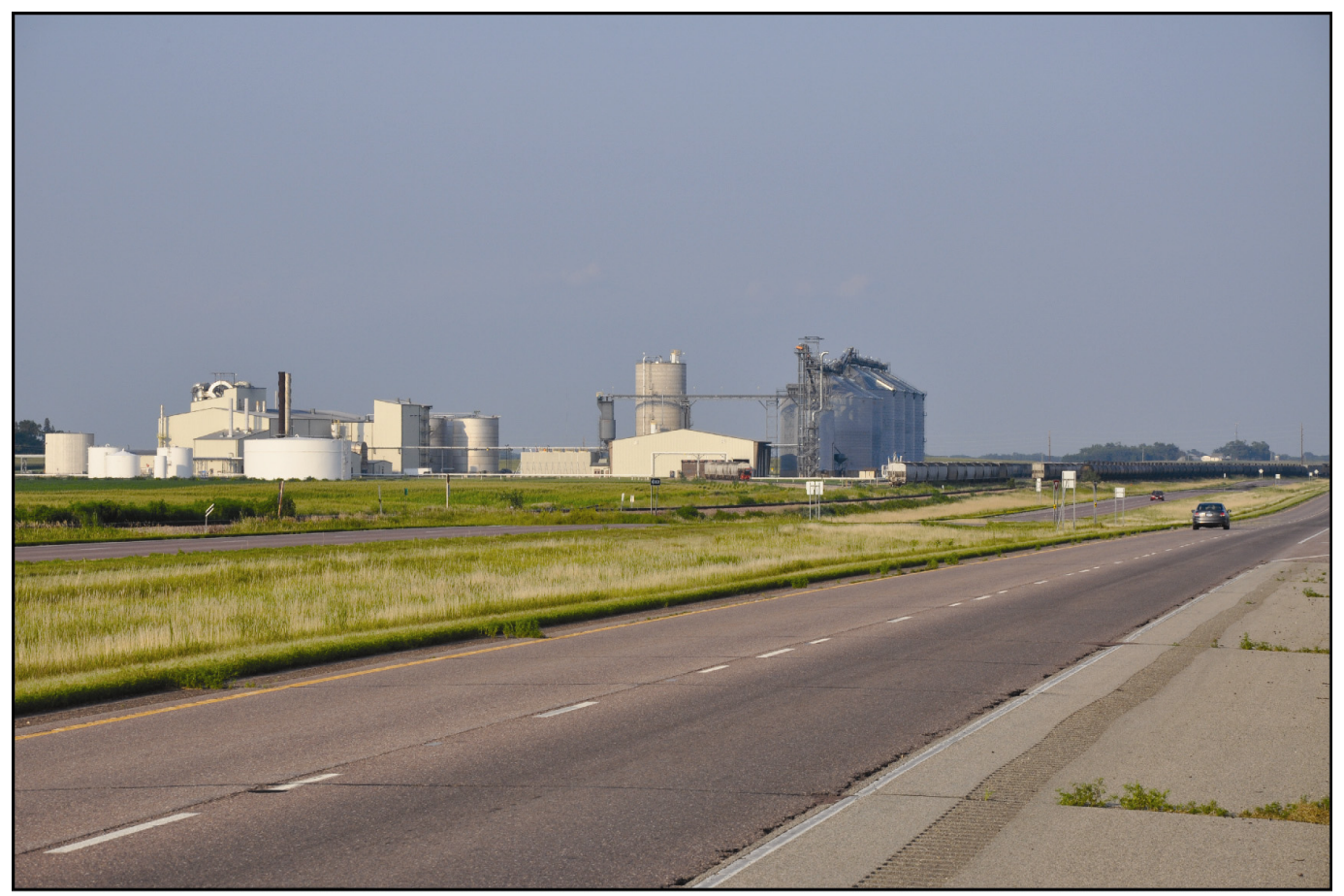

Figure 5. Ethanol distillation unit near Lake Crystal, MN

Table 2. Corn based Ethanol capacities and production units in Minnesota, 2012 (Millions of Gallons/Millions of Liters)

\begin{tabular}{lcl}
\hline Location & Capacity & Production \\
\hline Janesville & $110.0(416)$ & $110.0(416)$ \\
Welcome & $110.0(416)$ & $110.0(416)$ \\
Winthrop & $100.0(379)$ & $100.0(379)$ \\
Fergus Falls & $60.0(227)$ & $60.0(227)$ \\
Lake Crystal & $56.0(212)$ & $56.0(212)$ \\
Lamberton & $55.0(208)$ & $55.0(208)$ \\
Granite Falls & $52.0(197)$ & $52.0(197)$ \\
Atwater & $50.0(189)$ & $50.0(189)$ \\
Heron Lake & $50.0(189)$ & $50.0(189)$ \\
Winnebago & $49.0(185)$ & $49.0(185)$ \\
Preston & $46.0(174)$ & $46.0(174)$ \\
Claremont & $45.0(170)$ & $45.0(170)$ \\
Benson & $45.0(170)$ & $45.0(170)$ \\
Albert Lea & $42.0(159)$ & $42.0(159)$ \\
Marshall & $40.0(151)$ & $40.0(151)$ \\
Bingham Lake & $35.0(132)$ & $35.0(132)$ \\
Buffalo Lake & $25.0(95)$ & $25.0(95)$ \\
Morris & $24.0(91)$ & $24.0(91)$ \\
Luverne & $21.0(79)$ & $21.0(79)$ \\
Melrose & $2.6(9.8)$ & $2.6(9.8)$ \\
Fairmont & $115.0(435)$ & 0 \\
Little Falls & $21.5(81)$ & 0 \\
Minnesota Total & $1,154.1(4,367)$ & $1,017.6(3,852)$ \\
\hline Office \& Ren & Energy $)$ \\
\hline
\end{tabular}

Source: Nebraska Energy Office \& Renewable Energy Association, 2013. 
Employment directly related to ethanol climbed from 1,330 in 2000 to over 12,500 in 2011. Since much of the fuel is sold to an urban clientele, a situation clearly paralleling Minnesota's wind turbine industry, the revenue streams pouring into farmer owned co-operatives and the thousands of rural jobs they create result in a transfer of wealth from the state's metro areas to rural locales scattered throughout the southern half of Minnesota. Overall, ethanol production and its by-products added slightly over $\$ 900$ million to the value of the state's corn crop in 2011 (Minnesota, 2012).

As with wind turbines, the combination of government policies and favorable physical environmental conditions explain this situation with one slight difference being the government policies originate primarily from the federal rather state government. The physical environmental factors stem from rich soils borne of glacial deposition carpeting much of the southern half of the state and a warm and humid climate regime with a summer maximum of rainfall favoring dryland farming of corn and soybeans.

The first piece of federal legislation, the Alternate Motor Fuels Act of 1988, allowed the auto industry to avoid higher CAFÉ standards by manufacturing flex-fuel vehicles capable of burning E-85; a mixture of $85 \%$ ethanol and $15 \%$ gasoline. Relatively easy to implement since computer controlled air to fuel ratios and fuel injection rather than carburation became standard in the middle 1980's, the owners of flex fuel vehicles initially encountered a paucity of E-85 facilities, especially in the context of low oil and gasoline prices. However, this situation changed following the rapid rise and accentuated volatility associated with oil prices in the several years following the 9/11 attacks and the rapid growth of the Chinese economy.

Aside from targeting $\mathrm{SO}_{2}$ emissions from coal fired power plants, the Clean Air Act of 1990, Title II, forced the auto and light truck fleet to burn cleaner reformulated gasoline especially in regional settings noted for atmospheric stability, which inhibits air pollution dispersal. For example, summers in California are noted for temperature inversions at roughly 2,500 feet $(800 \mathrm{~m})$ while winters in the Midwest and Northeast are characterized by cold dense and stable air masses. Consequently, ethanol and Methyl Tertiary Butyl Ether (MTBE--an oxygenate derived from cracking oil) became the two favored additives. Both additives reduce carbon monoxide and ozone emissions by making combustion more complete or efficient. Ultimately, MTBE proved to be detrimental to groundwater supplies in California, its primary market, and as such Governor Schwarzenegger banned it in 2004 (Graves, 2003; Duffield et al., 2008). Ethanol became its replacement and overnight Minnesota and other Midwest distilleries experienced open access to the largest gasoline market in the United States.

With the Clean Air Act supplying the initial impetus to force refineries to mix ethanol into their final retail blend, several Midwestern States, lead by Minnesota in 1997, began to mandate a $10 \%$ ethanol mixture all year (Duffield et al., 2008). At a regional level, the bio-fuel, ethanol, effectively became the liquid fuel version of the electrical renewable energy standard. The U.S. E.P.A. recently raised the ethanol mixture ratio to $15 \%$ but concerns over liability of fueling older vehicles has severely limited implementation. (U.S. EIA, 2013d).

The Energy Policy Act of 2005 and the Energy Independence Act of 2007, which mandate 36 billion gallons of bio-fuels nationwide by 2022, reinforced the effects of the Alternate Motor Fuels Act and the Clean Air Act. Presently about $29 \%$ of Minnesota's corn crop supplies the ethanol industry. Critics point to the energy used to make ethanol and the industry's effect on raising grain prices and thereby food prices. However, dry-distillers grain, a major by-product of ethanol distillation sold as livestock feed, has a much higher protein content at $30 \%$ than raw corn's 9\% (Iowa State University, 2008). As distillation processes improve, greater yields with less water and fuel inputs are being realized. For example, at one of the state's newest distillation units located in Janesville, Minnesota, 3.0 gallons (11.3 liters) of ethanol are produced from one bushel of corn, an increase over the 2.6-gallon (9.8 liters) standard from circa 2005. Similarly, the plant uses 50\% less natural gas per gallon of fuel distilled relative to a distillation unit built in 1998 (Gales, 2011). As such, the Janesville facility, assuming local corn yields of 170 bushels per acre, will produce 510 gallons (1,930 liters) of ethanol per acre, a substantial increase over the industry standard of 350 gallons (1,325 liters) per acre from 10 years ago. These improvements close the gap on sugarcane's 750-gallon (2,840 liters) yield per acre and the 650-gallon (2,460 liters) yield of sugar beets (U.S. Dept. Agriculture, 2006).

A close examination of corn prices reveals they track crude oil prices very well. One must question the outcome of a scenario wherein corn prices return to $\$ 2$ per bushel, yet oil remained at $\$ 90-110$ per barrel. Would a farm level economic crisis ensue given the reliance on petroleum-based agro-chemicals and fuels required to achieve contemporary corn yields ranging from 150-200 bushels per acre? What impact would removal of ethanol have on gasoline prices since its removal would produce an instantaneous demand for another 650,00 barrels of oil per day? 
Likely near its capacity to generate ethanol based solely on corn as a feedstock Minnesota's next evolution would likely involve using part of the state's enormous sugar beet crop. Indeed, Minnesota ranks third in the United States behind Florida and Louisiana in sugar production. Another possibility centers on the use of switchgrass, a warm season grass native to the prairies of Minnesota. As a natural rather than agro-based feedstock, switchgrass possesses a near zero energy input as its chief attribute. However, the ability to distill its cellulosic structure with existing technology remains difficult and has thus far inhibited commercial scale operations.

\subsection{Biodiesel}

As noted, the U.S. consumes diesel fuel for on-highway and railroad transportation at roughly 2.6 million bbls/day in 2011, up from 1.525 million bbls/day in 1991. Indicative of just-in-time inventorying and reliance on motor truck transportation, $98 \%$ of this increase is attributable to on-highway transportation. Overall, distillate fuels for all purposes in the United States have risen from 2.9 million bbls/day in 1991 to 3.9 million bbls/day in 2011 (US EIA, 2013d).

Processed from mostly soybeans, bio-diesel accounted for 878 million gallons (3.32 billion liters) of fuel nationally and displaced slightly under $2 \%$ of the total demand for on-highway and rail in 2011 (US EIA 2013d). Utilizing about $15 \%$ of the state's soybean acreage, Minnesota in 2011 had two soybean-based processors with a capacity of 60 million gallons or 227 million liters (Minnesota, 2013) (Table 3). A third plant utilizing organic fats and oil currently produces 3 million gallons ( 11.5 million liters), but has the capability of expanding to 30 million gallons or 113.5 million liters (Minnesota, 2011) (Table 3). Possessing similar BTU characteristics to its petroleum-based counterpart, Minnesota's biodiesel production resulted in an $8 \%$ substitution for petroleum-derived diesel in 2011.

Table 3. Biodiesel capacities and production units in Minnesota, 2012 (Millions of Gallons/Millions of Liters)

\begin{tabular}{llll}
\hline Location & Capacity & Production & Feedstock \\
\hline Brewster & $30(114)$ & $30(114)$ & soybeans \\
Albert Lea & $30(114)$ & $30(114)$ & soybeans \\
Isanti & $3(11.4)$ & $3(11.4)$ & fry oils \\
Minnesota Total & 63 & 63 & \\
\hline
\end{tabular}

Source: Minnesota Dept. of Agriculture, 2013.

As with ethanol, Minnesota statutory requirements led the nation in essentially forcing a liquid fuel renewable energy standard and are chiefly responsible for the state's fledgling biodiesel industry (Minnesota, 2011). Specifically, a mandated $2 \%$ blend occurred in 2005, which increased to 5\% in 2009. Starting in May 2012, a $15 \%$ blend became required during the summer months (April through October), with an increase to $20 \%$ set for the summer of 2015. During the winters, a 5\% blend remains in effect (Minnesota, 2013). A federal tax credit of $\$ 1$ per gallon through December 31, 2013 applying to commercial blenders operates in tandem with the state mandates and is critical in narrowing the cost difference between bio-diesel and its petroleum counterpart to about 1.5 cents per gallon (Minnesota, 2011; Kotra, 2013). The short-term nature of the federal tax credit, set to expire on December 31,2013, blunts (a) the immediate incentive to expand production by increasing future uncertainty per its renewal and ultimate duration and (b) future state policy mandates by heightening the uncertainty of future supplies thereby increasing the possibility of waivers being issued in lieu of meeting more intense renewable bio-diesel standards.

Within Minnesota, biodiesel has resulted in over \$20 million in value added to the state's soybean crop with a $5 \%$ blend and yielded a commensurate decline in farm production subsidies (Biodiesel Council, 2006). The increased bio ratios encountered problems in the winter of 2010 pursuant to blending in cold weather and a temporary waiver for \#1 diesel was issued, though not for \#2 diesel (Minnesota, 2011). To achieve the B20 seasonal standard, Minnesota would need to produce roughly another 100 million gallons (378.5 million liters) to meet the 160 million gallon (606 million liter) demand created by a B20 standard (Minnesota, 2011). In 2010, about $30 \%$ of the soybean crop was exported to other states and foreign countries (Minnesota, 2010). To achieve the 100-million gallon (378.5 million liter) benchmark exclusively from soybeans based on existing acreage and yields, and assuming the 30 million-gallon (113.5 million liter) expansion of the fats and oils plant does not 
occur, about half the state's exports would cease. On the other hand, the aforementioned scenario would be altered by any of the following acting singly or in combination: (a) an increase in new acreage (assuming soybeans are not replacing corn), (b) yields beyond the current 41 bushels per acre, and (c) a 30 million gallon (113.5 million liter) expansion of the fats and oils unit.

\section{Conclusion}

Looking ahead, it seems unlikely the national mandate of 36 billion gallons of biofuels can be achieved with corn as the sole or overwhelming feedstock since $27 \%$ of the nation's crop now provides for a capacity of 14 billion gallons. Yielding only 63 gallons per acre (238 liters) rather than 450-500 gallons per acre (1,700-1900 liters) as with corn based ethanol, soybean based biodiesel has a long way to go before making a significant impact upon national consumption, although Minnesota stands a high probability of proving exceptional. Moreover, a major increase in soybean acreage also runs the risk of displacing corn since much of the Midwest operates on a two-crop rotation of corn and soybeans, with the latter being the junior partner in the rotation (2 years corn to one year soybeans).

Consequently, government policies need to target other feedstocks. For Minnesota, the possibility of using sugar beets grown in the Red River Valley seems enticing. Minnesota ranks first in the U.S. sugar beet production and current federal farm programs limit rather than maximize its production. Sugar beets also result in 650 gallons of ethanol per acre. Given the United States is nearly self-sufficient in sugar production, increases in sugar beets or sugar cane in Florida, Louisiana and Hawaii combined with supplemental imports from friendly Caribbean countries comprise another avenue for obtaining a more diversified set of feedstocks per ethanol distillation.

Another possibility involves cellulose-based ethanol distillation units relying on switchgrass, a warm season grass native to Minnesota. Growing abundantly and requiring very little energy inputs, the distillation process at the commercial level remains in a developmental or proto-type phase and would likely require a combination of government subsidies and mandates to launch and sustain a cellulosic industry, especially since the startup technologies will likely be costly, uncertain, and evolve rapidly resulting in the quick obsolescence of initial investments. Given the current deficits and gridlock within American governmental systems at the federal level, the short-term implementation of this option seems challenging at best. As for Minnesota "going it alone," the tradition of pioneering ethanol and biodiesel mandates set precedent for moving the biofuel frontier into a sugar beet and/or swiitchgrass set of feedstocks. On the other hand, I argue the developing bio-diesel program and other state funded operations, neglected due to the Recession, will most likely prevent a cellulosic program from being addressed and implemented solely by state government.

Overall, government policies and outright mandates forcing market creation for alternative biofuels or electrical generation capabilities along with long-term tax credits for producers have a proven record of achievement in Minnesota. The electrical Renewable Energy Standard with wind energy being paramount stands as a successful example. Often these mandates are coupled to environmental benefits associated with the federal Clean Air Act with corn-based ethanol being exemplary. Moreover, when the mandates engage gradually over time and build upon achieved production in the context of new industries and technologies, the probabilities of success are enhanced. Related to these lines of policy are tax subsidies and other economic forms of direct government assistance used to establish facilities characterized by: (1) high start-up costs and (2) new and un-proven technologies at a commercial scale that can easily become obsolete as the industry progresses beyond its incipient phases. Again, wind energy and corn-based ethanol are illustrative and bio-diesel appears, at least within Minnesota, to be on a similar trajectory.

Taken together these policy combinations level or at least reduce risks to a manageable level. Finally, when addressing biofuels that directly substitute for their petroleum-based counterparts, policies must ultimately foster the creation of multiple feedstocks to avoid the inherent risks of putting all one's eggs in a single basket. In this case, the opportunity costs of other crop uses, the possibility of a crop failure, or the exhaustion of the soil base with a single crop on a repetitive basis, remain as factors to be weighed and avoided in a successful long-term biofuel program. Finally, pro-active state policies operating in tandem with broader based federal policies can forcibly create viable alternative modes of energy production both in electricity and liquid fuels. Minnesota provides a stellar example.

\section{References}

Alternative Fuels Data Center. (2013). Fuel Properties Comparison. Retrieved April 19, 2013, from http://www.afdc.energy.gov/fuels/fuel_comparison_chart.pdf

Alternate Motor Fuels Act of 1988. (1988). Public Law 100-494. 
Clean Air Act of 1990, Titles II and IV. (1990). Statutes at Large 104:2468

Energy Policy Act of 2005. (2005). Statutes at Large 119:54

Energy Independence and Security Act of 2007. (2007). Public Law 110-140, HR 6.

Gales, D. (2011). Personal Communication. Data obtained while interviewing Don Gales, CEO Guardian Energy, LLC, Janesville MN 4/20/2011.

Graves, T. (2003). Methyl Tertiary Butyl Ether (MTBE): A Certification Problem. Journal of Natural Resources and Environmental Litigation, 17(2), 187-198.

Hoff, M., \& Michael, P. (2003). Catch the Wind: Minnesota's Wind Power Industry Is Picking Up Speed. Minnesota Conservation Volunteer, November-December 2003. Retrieved April 6, 2013, from http://www.dnr.state.mn.us/volunteer/novdec03/wind.html

Iowa State University. Agricultural Extension. (2008). Ethanol Coproducts for Cattle. Retrieved April 19, 2013, from http://www.extension.iastate.edu/Publications/IBC26.pdf

James, D., Irene, X., \& Steve, H. (2008). Ethanol Policy: Past, Present and Future. South Dakota Law Review, 53, 425-452.

Kotra, R. (2013). Gratitude and Concerns Expressed over Biodiesel Tax Credit Revival. Retrieved April 25, 2013, from http://www.biodieselmagazine.com/blog/article/2013/01/gratitude-concerns-expressed-over-biodieseltax-credit-revival

Minnesota. Department of Agriculture. (2010). Minnesota Soybean Statistics. Retrieved April 17, 2013, from http://www.mda.state.mn.us/food/business/ /media/Files/food/business/economics/soybeanindustry2010.as $\mathrm{hx}$

Minnesota. Department of Agriculture. (2011). Report to the Legislature: Annual Report on Biodiesel. Retrieved April 23, 2013, from http://www.mda.state.mn.us/news/government/ /media/Files/news/govrelations/ legrpt- biodiesel2011.ashx

Minnesota. Department of Agriculture. (2012). Minnesota Ethanol Industry. Retrieved March 28, 2013, from www.mda.state.mn.us/renewable

Minnesota. Department of Agriculture. (2013). About the Minnesota Biodiesel Program. Retrieved April 24, 2013, from http://www.mda.state.mn.us/renewable/biodiesel/aboutbiodiesel.aspx

Minnesota. Department of Commerce. (2008). Wind Velocities at 80 Meters. Retrieved April 12, 2013, from http://www.state.mn.us/mn/externalDocs/Commerce/80_Meter_Wind_Speed_013106115153_80MeterWind Speed.pdf

Minnesota. Department of Health. (2009). Public Health of Wind Turbines (St Paul) 10-20.

Minnesota. Office of Energy Security. (2011). Report to the Minnesota Legislature: Progress on Compliance by Electric Utilities with the Renewable Energy Standard. (St. Paul: MN Office of Energy Security) 1-12.

National Renewable Energy Lab. (1999). State Renewable Energy News 8:1. Retrieved April 21, 2013, from www.nrel.gov/analysis/sren/srenzz.pdf

Nebraska. State Energy Office. (2013). Ethanol Facilities Capacity by State and Plant. Retrieved April 4, 2013, from www.neo.ne.gov/statshtml/122.htm

Nelson, V. (2009). Introduction to Renewable Energy. (Boca Raton, FL: CRC Press) 181.

North American Water Office. (2008). Meeting Minnesota's Renewable Energy Standard Using the Existing Transmission System. Retrieved April 22, 2013, from www.c-bed.org/pdf/meetingminnesotares.pdf

Righter, R. (2011). Windfall: Wind Energy in America Today (Norman, OK: University of Oklahoma Press) 28.

Safe Water Drinking Act. (n.d.). Statutes at Large 100:642

Science Daily. (2008). Ecologists Allay Fears for Farmland Birds from Wind Turbines. Retrieved April 4, 2012, from http://www.sciencedaily.com/releases/2008/10/081001093500.htm

Science Daily. (2009). Scientists Find Successful Way to Reduce Bat Deaths at Wind Turbines, 2009. Retrieved from http://www.sciencedaily.com/releases/2009/09/090928095347.htm

Surface Mining and Reclamation Act of 1977. (n.d.). Statutes at Large 119:54

United States. Department of Agriculture. (2006). The Economic Feasibility of Ethanol Production from Sugar in 
the United States. Retrieved April 18, 2013, from http:/www.usda.gov/oce/reports/energy/ EthanolSugarFeasibilityReport3.pdf

United States. Department of Energy. (2013). Database of State Incentives for Renewables and Efficiency. Retrieved June 19, 2013, from http://www.dsireusa.org/incentives/incentive.cfm?Incentive_Code=MN14R

United States Energy Information Agency (US EIA). (2012). Domestic Uranium Report, pp. 4-12.

United States Energy Information Agency (EIA). (2013a). Summary Statistics for the United States, 2001-2011, Tables 2.13, 3.1a and 3.1b, 9.1. Retrieved March 20, 2013, from www.eia.gov/electrcity/annaul/html/epa_01_02.html

United States Energy Information Agency (EIA). (2013b). How Much CO2 Is Produced When Different Fuels Are Burned. Retrieved March 29, 2013, from http:/www.eia.gov/tools/faqs/faq.cfm?id=73\&t=11

United States Energy Information Agency (EIA). (2013c). Petroleum and Other Liquids: Product Supplied. Retrieved April 2, 2013, from www.eia.gov/dnav/pet/pet_cons_psup_dc_nus_mbblpd_a.htm

United States Energy Information Agency (EIA). (2013d). Biofuels Issues and Trends. Retrieved April 15, 2013, from www.eia.gov/biofuels, issuestrends/pdf/bit.pdf

Uranium Producers of America. (2013). US Historic Uranium Prodcution. Retrieved March 29, 2013, from http://www.uraniumproducersamerica.com/supply.html

Windpowering America. (2012). Installed capacity by State. Retrieved April 25, 2013, from www.windpoweringamerica.gov/.../installed_wind_capacity_by_state.xls

\section{Copyrights}

Copyright for this article is retained by the author(s), with first publication rights granted to the journal.

This is an open-access article distributed under the terms and conditions of the Creative Commons Attribution license (http://creativecommons.org/licenses/by/3.0/). 